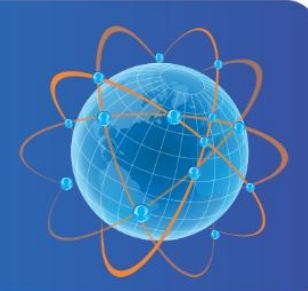

\author{
Resensi Buku : Digital Sociology \\ Authors : Budi Sutrisno \\ Published by : Departemen of Sociology, Faculty of Social and Political Science, \\ Universitas Padjadjaran \\ Accepted : December 2017; Approved : December 2017
}

Sosiogobal: Jurnal Pemikiran dan Penelitian Sosiologi is the Department of Sociology, Faculty of Social and Political Science, Universitas Padjadjaran flagship journal. The Sosioglobal journal founded in 2016 with the mission to publish original works of interest to the discipline of sociology in general, sociological thinking, new theoretical developments, results of research that enhance understanding of fundamental social processes, and methodological innovations. We are welcome a research article, working paper, theoretical/conceptual and methodological review to submit to our journal. In addition, we are accept relevant book review that currently publish and enrich sociological perspectives. Please submit article to http://jurnal.unpad.ac.id/sosioglobal 


\title{
Resensi Buku \\ Digital Sociology
}

\author{
Budi Sutrisno ${ }^{1}$ \\ Prodi Sosiologi, Fakultas Ilmu Sosial dan Ilmu Politik, Univeritas Padjadjaran \\ budi.sutrisno@unpad.ac.id
}

\section{Lupton, Deborah. 2015. Digital Sociology. London and New York:Routledge $\mathrm{v}+230$ hal}

Didalam buku setebal 230 halaman ini, Deborah Lupton memulai diskusinya dengan menggambarkan bagaimana keberadaan teknologi digital telah ikut menyatu didalam konteks sosial dan kelembagaan. Pengarang menyatakan bahwa saat ini kita hidup didalam masyarakat digital dan tentunya memberikan tantangan penting terhadap teori sosiologi dan praksisnya. Argumen tersebut didukung oleh penilaian pengarang terhadap pendekatan, perdebatan serta studi empiris terbaru yang mengelaborasi dimensi sosial, kultural dan politik dari teknologi digital. Lupton mendefinisikan sosiologi digital kedalam dua lokus yang berbeda yaitu sebagai sebuah praktik profesional dan analisa yang terfokus kepada penggunaan teknologi digital berikut data yang dihasilkannya. Hal ini yang kemudian secara eksplisit menjadikannya terhubung dengan disiplin ilmu lainnya seperti antropologi digital, studi kebudayaan, komunikasi massa dan studi tentang media.

Bagian awal buku ini dimulai dengan sebuah evaluasi secara luas terhadap keterkaitan antara teknologi dan masyarakat dari perspektif ilmu sosial, metode penelitian serta praktik akademis. Didalam dua bab pertama, Lupton memperkenalkan beberapa isu utama seperti kekuasaan, pengetahuan, produksi, konsumsi serta beberapa istilah yang biasa digunakan didalam teknologi komputasi seperti perangkat lunak (software) dan perangkat keras (hardware), objek data, jaringan hibrid, pengawasan (veillance), subjektivitas dan perwujudan (embodiment). Isu-isu tersebut dikaji melalui sebuah pengujian berlandaskan teori dan praktik penelitian dengan fokus kepada hubungan sosial yang termediasi secara digital.

Dua bab berikutnya membahas mengenai persinggungan antara teknologi digital, pendidikan tinggi dan praktik akademis. Pengarang juga mengelaborasi hubungan antara teori, metode penelitian dan data digital yang merupakan objek studi di era digital. Lupton mengkaitkan teori dan perkembangan metodologi serta memberikan contoh mengenai arah yang ditempuh para peneliti sosial didalam merespon proses digitalisasi. Secara eksplisit, bab ini terfokus 
kepada proses digitalisasi di dunia akademik dimana pengarang mencoba menggambarkan keterhubungan antara teknologi digital dan praktik akademik profesional. Dalam hal ini, pengarang membahas digitalisasi dunia akademik berdasarkan testimoni dan hasil survey terhadap mahasiswa yang menggunakan media sosial. Selain itu juga diperkaya dengan pengalaman pribadinya sebagai akademisi dan pegiat yang terlibat aktif didalam aktivitas "online".

Setelah mengelaborasi keterkaitan antara teknologi digital dengan Sosiologi, metode penelitian dan lembaga pendidikan maka empat bab terakhir terdiri dari eksplorasi mendetil terhadap isu-isu terpilih terkait dengan digitalisasi. Bagian pertama berisi analisa kritis terhadap data yang secara terus-menerus diproduksi oleh berbagai media digital. Selain itu juga kritik terhadap praktik pengawasan (surveillance) yang dilengkapi teknologi dan algoritma untuk memanen, menggali serta menyimpan data digital. Lupton melakukan analisa terhadap data yang besar dan kompleks (big data) tersebut yang kemudian "direpresentasikan sebagai bentuk lain superioritas dari pengetahuan" (hal. 93) sebagai artifak sosiokultural yang menyusun sistem pengetahuan, kekuasaan dan otoritas. Bagian selanjutnya menampilkan data statistik maupun kualitatif mengenai berbagai isu sosial dan politik terkait dengan penggunaan teknologi digital yang mencakup distribusi geografis, profil pengguna, ketidaksetaraan/ketimpangan yang muncul, isu gender, diskriminasi dan gambaran etnografi dari berbagai konteks kebudayaan yang berbeda. Dalam bab ini secara khusus dibahas mengenai politik digital serta keterlibatan publik dimana pengarang menyoroti berbagai pertanyaan seputar studi empiris mengenai pengawasan (veillance), kerahasiaan (privacy), aktivisme serta prakarsa mengenai keterbukaan data (open data). Setelah membahas dimensi politik dari praktik pengawasan (surveillance) dan privasi, Lupton kemudian memberikan pandangan kontras terhadap retorika positif mengenai kemungkinan penggunaan media sosial secara progresif untuk mendorong transformasi sosial, transparansi serta memudahan akses terhadap informasi. Pengarang berargumen bahwa media sosial juga dapat digunakan untuk menyebarkan informasi yang salah (hoax), perlakuan diskriminatif serta ujaran kebencian (hate speech).

Kontribusi yang juga menarik dari buku ini adalah analisa mengenai keintiman (intimacy) dan meleburnya batasan diantara ranah publik dan privat yang menekankan pada dimensi tubuh, kontak fisik dan hubungan afektif diantara manusia yang tercipta melalui teknologi digital. Dalam hal ini teknologi digital semakin meningkat perannya didalam pembentukan relasi antara tubuh, ruang dan praktik menonjolkan diri (narcism). Pengarang memberikan 
pendapatnya berdasarkan penelitian yang dilakukan dua dekade lalu yang menyoroti transformasi penting yang terjadi tidak hanya didalam hardware, software dan konektivitas jaringan tetapi juga hubungan mendalam diantara manusia yang tercipta melalui teknologi digital. Kesimpulan dari bab ini ditutup oleh penilaian terhadap relevansi teknologi digital bagi para sosiolog serta beberapa pandangan dari para peneliti yang berfokus kepada kehidupan sosial digital.

Buku Sosiologi Digital karta Deborah Lupton ini memberikan sumbangan perspektif terhadap hubungan sosial yang terdigitalisasi. Selain itu juga menggambarkan digitalisasi sebagai sesuatu yang cukup komplek untuk dipahami, berdimensi plural serta merupakan objek analisis yang saling terhubung secara mendalam dan memberikan dampak terhadap disiplin Sosiologi. Buku ini cukup ringkas tetapi ambisius didalam pembahasan serta ruang lingkupnya. Kritik terhadap buku ini, pembahasannya cenderung mengarah kepada dunia digital Anglosaxon dengan banyak mengambil peristiwa di negara Amerika Utara, Australia dan Inggris baik dalam pilihan literaturnya maupun konteks sosialnya. Hal ini kemungkinan disebabkan kemajuan yang telah diraih oleh wilayah tersebut-dan juga pengarang yang tinggal di Australia - dalam pengetahuan dan ekonomi global, ekologi media digital dan kemajuan bidang akademik Sosiologi sendiri tentunya. Selain itu juga disebabkan oleh status bahasa Inggris yang menjadi lingua franca dari teknologi Internet. Meskipun pengarang secara eksplisit berupaya untuk memberikan gambaran statistik dan etnografi mengenai perkembangan teknologi digital di belahan bumi lainnya.

Namun demikian, buku ini tetap berupaya memberikan tinjauan kritis dan berimbang mengenai digitalisasi dunia sosial. Sejalan dengan tradisi kritis dan refleksif dari Sosiologi maka turut pula dieksplorasi dan dianalisa mengenai hubungan kekuasaan dan dimensi ketidakadilan, diskriminasi dan eksploitasi. Sebagai penutup, buku ini dipandang cukup bernilai dan dapat dijadikan peta pembuka bagi studi sosiologi digital selanjutnya. Selain itu juga memberikan informasi kepada para pembaca mengenai perkembangan dunia sosial kontemporer. 